\title{
Correlation Between Testosterone Concentrations with Scrotal Circumference, and Semen Characteristics in Aceh Bulls
}

\author{
Dasrul Dasrul $^{1 *}$, Sri Wahyuni ${ }^{2}$, Sugito Sugito ${ }^{3}$, Abdulah Hamzah $^{3}$, Zulzya Zaini $^{4}$, Abdul Haris ${ }^{5}$, and Gholib Gholib ${ }^{6}$ \\ ${ }^{1}$ Laboratory of Reproduction, Faculty of Veterinary Medicine, Universitas Syiah Kuala, Banda Aceh 23111 Indonesia \\ ${ }^{2}$ Laboratory of Anatomy, Faculty of Veterinary Medicine, Universitas Syiah Kuala, Banda Aceh 23111 Indonesia \\ ${ }^{3}$ Laboratory of Clinical Pathology, Faculty of Veterinary Medicine, Universitas Syiah Kuala, Banda Aceh 23111 Indonesia \\ ${ }^{4}$ Department of Animal Husbandry and Veterinary, Aceh Province, Banda Aceh, Indonesia 23111 Indonesia \\ ${ }^{5}$ Laboratory of Pharmacology, Faculty of Veterinary Medicine, Universitas Syiah Kuala, Banda Aceh 23111 Indonesia \\ ${ }^{6}$ Laboratory of Physiology, Faculty of Veterinary Medicine, Universitas Syiah Kuala, Banda Aceh 23111 Indonesia
}

\begin{abstract}
This study was conducted to examine testosterone concentrations its relationship with the scrotal circumference and physical characteristics of semen in aceh bulls. Semen samples were collected weekly from jugular vein of three aceh bulls aged 4-5 years old for 10 weeks. Testosterone concentration was measured by enzyme-linked immunosorbent assay (ELISA) method. Semens were collected by using artificial vagina and evaluated for physical characteristics namely ejaculatory volume, $\mathrm{pH}$, and sperm motility, concentration, and abnormalities. Data were analyzed using correlation-regresion test. Testosterone concentrations showed a positive correlation with scrotal circumference $(r=0.799)$, number of sperm $(r=$ $0.703)$, sperm motility $(r=0.857)$ and sperm abnormalities $(r=-0,877)$. No correlation, however, was found between testosterone concentrations with semen volume $(\mathrm{r}=0.038)$ and $\mathrm{pH}(\mathrm{r}=0.418)$. It can be concluded that testosterone concentrations correlated positively with scrotal circumference, numbers of sperm, sperm of motility and sperm of abnormality.
\end{abstract}

Keywords: Aceh bulls, testosterone concentration, scrotal circumference and semen characteristics

\section{Introduction}

Aceh cattle is one of Indonesian beef cattle germplasmas native to Indonesia, that have been bred by farmers in Aceh province for meat production and workforce [1]. According to Abdullah [2], Aceh cattle belong to small beef cattle breed genetically have unique genes and different from other native Indonesian cattle pools such as Bali cattle, Madura cattle, Pasundan cattle and Ongole cattle. Although having growth rate smaller than crossbred cattle, Aceh cattle have been well adaptive to Indonesian environment that is warm, humid, and having insufficient food and water, and prevalent of parasitic diseases [3]. Population numbers and genetical quality of Aceh cattle, however, tend to decrease [1].

Efforts to increase population and genetic quality of Aceh cattle have been done by optimizing reproduction efficiency by the application of artificial insemination (AI). Application of AI technology is not only able to increase productivity and accelerate distribution of catlle populations have good genetic quality, but also is expected to be able to optimize function of a bull $[4,5]$. The success of AI program in animal is closely related to quality of sperms ejaculated by a bull. Effort to select a bull has good performance and high fertility. This condition is related to the ability of a bull to produce high fertility spermatozoa [6]. One of the ways to determine fertility rate of a bull is by investigating capacity of spermatozoa production that can be indirectly predicted by measuring serum testosterone and scrotum circumference. This is because spermatozoa were formed by epithelial cells called spermatogonia that are located inside the seminiferus tubules of testes. Testes productivity in producing spermatozoa is dependent upon the numbers of spermatogonia cells performed mitosis and meiosis cleavages [5], and testes ability to produce testosterone [7]. The higher testosterone concentration the better production of substrates are responsible for regulating and performing spermatogenesis activity $[8,9,10]$. Some studies have analyzed the relationship between serum testosterone concentration, sperms quality and fertility of bulls, and some of them reported a strong correlation $[11,12,13]$, but other could not find any association [10].

Data on the level of testosterone hormone in the serum, scrotal circumference, and semen characteristics (semen volume and $\mathrm{pH}$ as well as sperms motility, concentration and abnormality) of Aceh bulls have been not reported so far. This condition becomes a problem in developing Aceh cattle breeding program. Therefore, it is

Corresponding author: dasrul.darni@yahoo.com 
necessary to conduct a study that able to contribute to basic information about serum testosterone level, scrotal circumference, and semen quality of Aceh bulls in the UPTD-BIBD of Saree, Aceh Besar.

\section{Materials and Methods}

\subsection{Research design}

This study was a field observational research used three adult, healthy Aceh bulls aged 4.0-5.0 years old and had body weight ranged from $300-350 \mathrm{~kg}$, all of which were kept at the Technical Implementation Unit and Local Artificial Insemination Agency (UPTD-BIBD) of Saree, Aceh Besar. The bulls were kept in individual close cages equipped with feeding and drinking facilities. Animals were fed with concentrate $(3.0 \mathrm{~kg} / \mathrm{head} /$ day $)$ and fresh grass (30-35 kg/head/day). The concentrate was given in the morning whereas fresh grasses were provided ad libitum in the midday and afternoon. Measurement of scrotal circumference, collection of whole blood and semen samples were done every week from 10 consecutive weeks.

\subsection{Measurement of scrotal circumference}

Scrotal circumference $(\mathrm{cm})$ was measured at a week interval by measuring tape had one tenth accuracy. Prior to every measurement, testes were palpated and slowly pressed downward to allow them enter scrotal cavity. Measurement tape was circled at the neck of scrotum and moved downward until reaching the biggest scrotal curvature and recorded.

\subsection{Blood collection and preparation}

Whole blood samples were withdrawn from jugular vein of three Aceh bulls weekly for 10 consecutive weeks at 07.00-08.00 am using plain collection tubes (BD Vacutainer, Franklin Lakes, NJ, USA). Tubes containing sample were put at slanted position at $4-5{ }^{\circ} \mathrm{C}$ for $4-5$ hours. Serums formed were separated by centrifugation at $1,500 \mathrm{xg}$ for 15 minutes and stored at $-20^{\circ} \mathrm{C}$ until used in next experiment.

\subsection{Measurement of serum testosterone levels}

Serum testosterone was measured by using a commercial Testosterone ELISA kit (Cat. No. EIA-1559,DRG Instrument $\mathrm{GmbH}$, Germany). This assay has been validated for Aceh bulls [14] and other animals [15,16]. In brieft, all serums were diluted 1:4 using aquabidestilata. Standard solutions having concentration ranged from 0.2-16 $\mathrm{ng} / \mathrm{ml}$ were prepared. Samples and standard solutions, $25 \mu \mathrm{l}$ each, were transferred in triplicate into wells of ELISA microplate, added with conjugate enzyme (except for blank) and covered with a cling film. Mixtures were homogenized by shaking it gently for 10 seconds and incubated at room temperature for 60 minutes. Microplate wells were washed 3-4 times with masing $300 \mu$ l of washing solution, added with 200 $\mu l$ of substrate, and incubated at room temperature for 15 minutes. Reaction was stoped by the addition of $100 \mu \mathrm{l}$ of stop solution $\left(0.5 \mathrm{M} \mathrm{H}_{2} \mathrm{SO}_{4}\right)$ to each well. Absorbance was read using ELISA reader at $450 \mathrm{~nm}$.

\subsection{Semen collection and evaluation}

Semen samples were collected weekly from 3 Aceh bulls for 10 consecutive weeks at 08.00 am by using artificial vagina $42-45^{\circ} \mathrm{C}$. Semens were evaluated macroscopically (volume, color, odor, $\mathrm{pH}$ and consistency) and microscopically (spermatozoa concentration, motility and abnormality). Semen volume was measured by scaling reaction tube whereas its $\mathrm{pH}$ was determined using a digital pH-meter. Spermatozoa concentration was counted by using a Haemocytometer as described by [17]. Spermatozoa motility was evaluated by observed a drop of semen sample onto a deck glass using a light microscope (Olympus). To evaluate spermatozoa morphology, semen samples were fixed using a formalin solution (99 ml sodium citrate $2.9 \%+1 \mathrm{ml}$ of $37 \%$ formaldehyde).

\subsection{Data analysis}

The relationships between testosterone level and scrotal circumference and semen characteristics were evaluated by using correlation analysis tested followed by a regression analysis.

\section{Results and Discussions}

Average measurement results of serum testosterone level, scrotal circumference and fresh semen characteristics (semen volume and $\mathrm{pH}$, spermatozoa concentration, motility and abnormality) of Aceh bulls evaluated are presented in Table 1.

Tabel 1. Serum testosterone, the scrotal circumference of semen characteristics of Aceh cattle bulls kept at the UPTDBIBD of Saree, Aceh Besar

\begin{tabular}{|c|c|c|}
\hline Parameter & Mean \pm SD & $\begin{array}{l}\text { Normal } \\
\text { range }\end{array}$ \\
\hline Serum testosterone (ng/ml) & $7.95 \pm 2.85$ & $5.14-13.06$ \\
\hline Scrotal circumference $(\mathrm{cm})$ & $\begin{array}{l}28.02 \pm \\
2.23\end{array}$ & $\begin{array}{c}24.80- \\
32.80\end{array}$ \\
\hline Semen volume (ml/ejaculate) & $4.70 \pm 0.61$ & $3.70-5.80$ \\
\hline Semen $\mathrm{pH}$ & $6.98 \pm 0.15$ & $6.80-7.20$ \\
\hline $\begin{array}{l}\text { Spermatozoa number } \\
\left(10^{9} / \mathrm{ml}\right)\end{array}$ & $1.40 \pm 0.72$ & $1.12-1.69$ \\
\hline Spermatozoa motility (\%) & $\begin{array}{c}77.00 \pm \\
3.40\end{array}$ & $\begin{array}{l}70.00- \\
80.00\end{array}$ \\
\hline $\begin{array}{l}\text { Spermatozoa abnormality } \\
(\%)\end{array}$ & $9.60 \pm 2.04$ & $7.00-14.00$ \\
\hline
\end{tabular}

\subsection{Serum testosterone levels in Aceh bulls}

Serum testosterone levels of Aceh bulls examined in this study ranged from $5.14-13.06 \mathrm{ng} / \mathrm{ml}$ with the average of $7.95 \pm 2.85 \mathrm{ng} / \mathrm{ml}$. Average serum testosteron level found in this study was relatively similar to those reported in Ongole crossbred cattle, $7.0 \pm 0.8 \mathrm{ng} / \mathrm{ml}$ [18], but slightly 
higher than those found in Simmental bull $6.1 \pm 0.4 \mathrm{ng} / \mathrm{ml}$ [18], Friesian Holstein (FH) bull aged 3 - 4 years old 2.07 $\pm 1.12 \mathrm{ng} / \mathrm{ml}$ [13], and adult FH bulls $5.66 \pm 1.08 \mathrm{ng} / \mathrm{ml}$ [10]. Variation of blood testosterone levels might caused by many factors such as breed, climate, rations and age $[19,20,21,22]$ as well as sensitivity and accuracy of measurement methods used [23].

\subsection{Scrotal circumference of Aceh bulls}

Scrotal circumference is a central circumference of both testes determined by measuring the largest central part of scrotum after testes are pressed downward into scrotum cavity. Scrotal circumference of Aceh bulls kept at the UPTD-BIBD of Saree Aceh Besar ranged from 24.80$32.80 \mathrm{~cm}$, average circumference was $28.02 \pm 2.23 \mathrm{~cm}$. Average scrotal circumference of Aceh cattle examined in the study is comparable to those reported by Fadhli [23] in Aceh e bulls aged 3-5 kept in intensive system $(28.28 \pm 2.20 \mathrm{~cm})$ and Bali bulls aged 6-7 years old $(28.70$ $\pm 2.30 \mathrm{~cm}$ ). Scrotal circumference of Aceh bulls recorded in this study was higher than that of reported by Toleng et al. [24] in Bali bulls aged 3-4 years old 23,2 cm. Among factors might infleuced were age, body weight, nutritional status and environment. Hight scrotal circumference of Aceh bulls may be caused by the age of bull examined had reached puberty and body maturation as reflected by their average body weight. Moreover, Aceh bulls examined are bulls kept for semen production so that they have passed selection process based on reproduction organ criteria. According to Ratnawati and Affandhy [25]improved body condition or bodyweight will give a response to enlargement of scrotal size. Khairi [26] also added that scrotal size is positively correlated with the cattle body size or weight.

\subsection{Semen volume and $\mathrm{pH}$}

Semen volume (ml) of Aceh bulls examined in this study ranged from $3.70-5.80 \mathrm{ml} /$ ejaculation, with average of $4.70 \pm 0.61 \mathrm{ml} /$ ejaculation. The $\mathrm{pH}$ of the semen ranged from 6.8 - 7.2., with average of adalah 7.01 \pm 0.08 . Average semen volume and $\mathrm{pH}$ obtained were relative similar to those reported by Zaini et al. [27] at Aceh bulls aged 3-4 years old, $3.82 \pm 0.47 \mathrm{ml}$ and $6.84 \pm 0.17$, respectively. The semen of Bali cattle also have relative similar volume and $\mathrm{pH}$ namely $4.83 \pm 1.40 \mathrm{ml}$ and $6.51 \pm 0.12$ [28]. The volume of semen obtained, however, relatively higher than those of PO cattle aged 2-3 years old, $2.6 \pm 1.5 \mathrm{ml}$. variation of semen volume reported might be related to the diferences in animal species, age, and body weight, as well as climate and raising management. Different average colume and $\mathrm{pH}$ of bovine semen are influenced by spesies, age, body weight, collection interval and environmental condition [5,28,29] and scrotal circumference [30]. In this study, all Aceh bulls used as semen sources have been trained to be a bull for semen collection..

\subsection{Spermatozoa concentration, motility and abnormality}

Evaluation on spermatozoa concentration, motility and abnormality is very important because these factors represent semen properties used as criteria for determining semen quality. Average spermatozoa concentration, motility and abnormality of Aceh bulls evaluated in this study were $1.40 \pm 0.72 \times 10^{9} \mathrm{sperms} / \mathrm{ml}$, $77.00 \pm 3.40 \%$ and $9.60 \pm 2.04 \%$, respectively. Values reported are relatively similar to those reported in Bali cattle kept at the UPTD-BIB Maros i.e. $1.513 \times 10^{9}$ sperms $/ \mathrm{ml} ; \quad 61 \pm 13.0 \%$ and $10.8 \pm 1, .8 \%$ [31] Spermatozoa numbers, motility and abnormality of Aceh bulls reported, however, are higher than those reported in Bali cattle namely $1.02 \pm 0.32 \times 10^{9} \mathrm{sperms} / \mathrm{ml}, 67.02 \pm$ $6.92 \%$ and $3.89 \pm 1.43 \%$ [28]. The differences in values reported might be related to species, age, body weight, ransom and environment of cattle used. These are in accordance to previous reports showing semen characteristics were influenced by age, fed quality, body weight, collection frequency and environment [27,28,29,32].

\subsection{The relationships of serum testosterone level and scrotal circumference and semen characteristics of Aceh bulls}

Results of correlation analysis on testosterone serum level and scrotal circumference and semen characteristics (volume and $\mathrm{pH}$, and spermatozoa concentration, motility dan abnormality) of Aceh bulls in the UPTD-BIBD Saree Aceh Besar are listed in Table 2.

Table 2. Correlation coefficient values (r), determinant coefficient $\left(\mathrm{r}^{2}\right)$ and linier formula of the relationship of serum testosterone levels and scrotal circumference and semen characteristics of Aceh bulls in the UPTD-BIBD Saree Aceh Besar

\begin{tabular}{lcccc}
\hline \multicolumn{1}{c}{ Parameter } & $\begin{array}{c}\text { Correlation } \\
\text { coefficient } \\
(\mathrm{r})\end{array}$ & $\begin{array}{c}\text { Determinat } \\
\text { coefficient } \\
\left(\mathrm{r}^{2}\right)\end{array}$ & $\mathrm{P}$ & Liniar Formula \\
\hline Scrotal circumference & 0.799 & 0.639 & $0.000^{* *}$ & $\mathrm{Y}=1.021 \mathrm{x}-20.67$ \\
Semen volume & 0.038 & 0.001 & 0.872 & $\mathrm{Y}=0.178 \mathrm{x}+7.108$ \\
Semen pH & 0.418 & 0.175 & 0.066 & $\mathrm{Y}=0.088 \mathrm{x}+7.069$ \\
Spermatozo concentration & 0.703 & 0.494 & $0.001^{* *}$ & $\mathrm{Y}=0.007 \mathrm{x}-2.212$ \\
Spermatozoa motility & 0.857 & 0.734 & $0.000^{* *}$ & $\mathrm{Y}=0.536 \mathrm{x}-32.534$ \\
Spermatozoa abnormality & -0.877 & 0.769 & $0.000^{* *}$ & $\mathrm{Y}=-1.137 \mathrm{x}+19.318$ \\
\hline
\end{tabular}

Note: $* *$ in coloum shown a significant effect $(\mathrm{p}<0.01)$, while tn shown not significant effect $(\mathrm{p}>0.05)$

Based on result of analysis presented in Table 2, concentration of serum testosterone positively correlated with scrotal circumference in Aceh bulls $(r=0.799)$ as shown by a regression formula $\mathrm{Y}=0.178 \mathrm{x}+7.108$. This means that higher serum testosterone level proportional to larger scrotal circumference. This finding was in 
agreement to those reported by Fadli [22] who found strong correlation between serum testosterone and scrotal circumference of Aceh bulls aged 3-5 years old kept in intensive system $(r=0.719)$. Other study in Simelue buffalo aged 4-5 years old shown relative similar results, $r=0.954$ [21]. These results showed that adult Aceh cattle already have completely matured and fully functional reproductive organs and accessorial glands to allow adequate serum testosterone and spermatozoa. Some researchers previously reported that Leidig cells in the testes of adult cattle active in synthesizing testosterone.

Results of this study also showed that serum testosterone level of Aceh bulls positively correlated with semen volume with a correlation coefficient (r) of 0.038 and regression formula $\mathrm{Y}=0.178 \mathrm{x}+7.108$, also on semen $\mathrm{pH}$ with a correlation coefficient (r) 0.418 and regression formula of $\mathrm{Y}=0.088 \mathrm{x}+7.069$. Correlation property between testosterone concentration and semen volume and $\mathrm{pH}$ of Aceh bulls could be categorized as very low and medium. This result showed that increased testosterone concentration did not influence semen volume and $\mathrm{pH}$ in Aceh bulls. These findings were different from those reported by Rachmawati et al. [33] in Bligon goats that serum testosterone concentration significantly associated with semen volume $(\mathrm{P}<0.01), \mathrm{r}=$ 0.65 . Blood testosterone level plays a role in determining spermatozoa concentration and motility rate of cattle [1[10], and Bligon and Kejobong goats [33].

Serum testosterone level of Aceh cattle strong- and significanty correlated with spermatozoa concentration $(\mathrm{r}$ $=0.703)$ and motility $(\mathrm{r}=0.857)$. These mean that higher serum testosteronelevel will be followed by higher spermatozoa numbers and motility percentage in Aceh bulls. These results are consistent with Rachmawati et al [33], who reported positive correlation between testosterone concentration and spermatozoa numbers in Bligon goats $(r=0.72)$. This condition might be caused by testosterone role in stimulating spermatogenesis so that spermatozoa concentration in the semen also increased. Testosterone is a hormone involved in spermatogenesis process, especially at spermatositogenesis and spermiogenesis phases of spermatozoa maturation (Sulisbury and VanDemark, 1985). Adequate testosterone concentration will result in faster differentiation of spermatogonia cell into spermatocyte and transfomation of spermatid into spermatozoa, resulting in more spermatozoa to ejaculate [5]. Determination coefficient of 0.703 found between serum testosterone level and spermatozoa concentration indicated that serum testosterone concentration only $70.3 \%$ influenced spermatozoa concentration, and the rest was associated with other factors. Correlation coefficient values obtained between serum testosterone level and spermatozoa concentration in Aceh cattle supported results of study by Rachmawati et al [33] that serum testosterone level positively correlated $(\mathrm{r}=0.59)$ with spermatozoa concentration in goats. Higher coefficient correlation of serum testosterone level and spermatozoa concentration in Aceh bulls included in this study compared to those reported Sajjad et al. [7], suggested that serum testosterone concentration was not significantly affect the spermatozoa concentration of buffalo with a correlation coefficient of 0.264 .

Results of this study also found that serum testosterone negatively associated with spermatozoa abnormality in semen $(\mathrm{P}<0.05), \mathrm{r}=-0.877$. This result gave evidence that higher serum testosterone level resulted in less spermatozoa abnormality. This finding is in agreement to that reported by previous researchers that shown negative correlation of testosterone level with spermatozoa abnormality in adult Kejobong goats [9], buffaloes [12], and FH crossbred [10], suggested that healty adult produce better and higher testosterone hormone than young animals. More testosterone hormone available to be used in spermatogenesis due to matured reproductive organs and sex glands will resulted in higher quality of semen compared to that produced by young animals. High testosterone may increase spermatozoa concentration, motility and viability in semen $[9,10,12,21]$.

\section{Conclusions}

Serum testosteroane level strongly correlated with scrotal circumference, sperms concentration and sperms motility of Aceh bulls whereas semen volume and $\mathrm{pH}$, and sperms abnormality were not associated with serum testosterone levels.

Further research needs to do in order to investigate the relationship between serum testosterone concentration with libido, semen quality and spermatozoa fertility rate of Aceh bulls after freezing.

\section{References}

1. Dinas Kesehatan Hewan dan Peternakan Aceh: Laporan Tahunan. Banda Aceh. 2017.

2. Abdullah MAN: Karakteristik genetik sapi Aceh menggunakan analisis keragaman fenotip, daerah DLoop DNA mitokondria dan DNA mikrosatelit. Disertasi. Sekolah Pascasarjana. Institut Pertanian Bogor. 2008.

3. Gunawan: Upaya Peningkatan Mutu Genetik Sapi Aceh. Pidato Pengukuhan dalam Jabatan Guru Besar Tetap Fakultas Pertanian Universitas Syiah Kuala. Disampaikan pada Rapat Senat Terbuka Universitas Syiah Kuala, Sabtu 28 Maret 1998 di Banda Aceh. 1998

4. Arifiantini RI, Yusuf TL: Keberhasilan penggunaan tiga pengencer dalam dua jenis kemasan pada proses pembekuan semen sapi Frisian Holstein. Majalah Ilmiah Peternakan. 2006; 9(3): 145-152

5. Hafez ESE: Reproduction and Breeding Techniques for Laboratory Animals. Philadelphia. Lea and Febinger. 2007.

6. Toelihere MR: Fisiologi Reproduksi Pada Ternak. Bandung. Angkasa. 1993.

7. Sajjad M, Ali S, Ullah N, et al. : Blood serum testosterone level and its relationship with scrotal circumference and semen characteristics in Nili-Ravi bufallo bulls. Pakistan Vet. J. 2007; 2: 63-66

8. Souza LWO, Andrade CFA, Celeghini CEE, et al. : Correlation between sperm characteristics and 
testosterone in bovine seminal plasma by direct radio immunoassay. R. Bras. Zootec. 2011; 40(12): 2721-2724

9. Syamyono O, Samsudewa D, Setiatin TE: The correlation of scrotal circumference and body weight, semen volume, semen quality and testosterone levels of young and adult Kejobong bucks. Buletin Peternakan. 2014; 38(3): 132-140.

10. Rajak SK, Tripathi KU, Attupuram MN, et al. : Relationship of blood and seminal plasma testosterone concentrations with semen quality in crossbred bulls. Indian J. Dairy Sci. 2014; 67(2): 162-167.

11. Hastomo I, Arifin J: Pengaruh lingkar skrotum terhadap kandungan testosteron, volume semen dan konsentrasi sperma domba Garut. Laporan Penelitian. Bandung: Fakultas Peternakan Universitas Pajajaran. 2004.

12. Javed MA, Khan A, Ali M: Influence of season on seminal plasma testosterone and oestrogen in healthy and abnormal buffalo bulls and their relationship with other semen parameters. Vet. Arhiv. 2000; 70: 141-149

13. Dameanti FNAEK, Rudy SS, Srianto P: Kadar testosteron sapi pejantan yang digunakan untuk proses produksi semen beku di Taman Ternak Pendidikan Fakultas Kedokteran Hewan Universitas Airlangga. Surabaya. Fakultas Kedokteran Hewan. Universitas Airlangga. 2010.

14. Gholib G, Wahyuni S, Akmal M, et al.: The validation of a commercial enzyme-linked immunosorbent assay and the effect of freeze-thaw cycles of serum on the stability of cortisol and testosterone concentrations in Aceh cattle. F1000Research. 2019; 8:1220

15. Gholib G, Wahyuni S, Kadar OK, et al. : Measurement of serum testosterone in kacang goat by using enzymelinked immunosorbent assay (ELISA) technique: the importance of kit validation. Jurnal Kedokteran Hewan, 2016; 10(1):32-36

16. Akmal M, Gholib G, Rinidar, et al. : The concentration of testosterone, pituitary adenylate cyclase-activating polypeptide, and protamine 1 in the serum of male chicken following administration of epididymis and testicular extracts and their combination. Veterinary World. 2019; 12(7): 1101-1107

17. Salisbury GW, Van Demark LN: Fisiologi Reproduksi dan Inseminasi Buatan Pada Sapi. Diterjemahkan oleh R. Djanuar. Yogyakarta. Gadjah Mada University Press. 1985

18. Rashid A, Affandhy L, Wijono DB: Profil hormon testosteron dan kualitas semen sapi pejantan Peranakan Ongole dan silangan Simmental. Seminar Nasional Teknologi Peternakan dan Veteriner. 2003; Puslitbang Peternakan. Bogor 29- 30 September 2003.

19. Gulia S, Sarkar M, Kumar V, et al. : Divergent development of testosterone secretion in male Zebu (Bos indicus) and crossbred cattle (Bos indicus $\times$ Bos taurus) and buffaloes (Bubalus bubalis) during growth. Trop. Anim. Health Prod. 2010; 42:1143-1148

20. Affandhy L, Fitrayady HP, Luthfi M, et al. : Effect of live weight on libido, sperm quality, testosterone and luteinizing hormone in replacement stock of Ongole grade bull. J. Indonesian Trop. Anim. Agric. 2018; 43(4):352-360.
21. Qadarsina Q, Dasrul D, Wahyuni S: Konsentrasi Hormon Testosteron Kerbau Simeulue dan Korelasinya dengan Tingkat Umur dan Lingkar Skrotum. Jurnal Agripet . 2019; 19(1): 13-21

22. Fadhli Z: Kadar testosteron sapi aceh pada berbagai tingkat umur dan hubungan dengan lingkar skrotum, bobot badan dan pola pemeliharaan. Tesis. Program Studi Kesehatan Masyarakat Veteriner Universitas Syiah Kuala. 2016.

23. Pineda MH, Dooley PM: Veterinary Endocrinology and Reproduction. 5th ed. Iowa: Blackwell Publishing. 2003.

24. Toleng AL, Yusuf M, Rahardja DP, et al. : Interrelationship Of Some Parameters On The Quality of Bali Bulls Sperms Kept Under 61 Smallholder Farms. Proceeding Of The 16th AAAP Animal Science Congress.Vol. II 10-14 November, Gadjah mada University, Yogyakarta, Indonesia. 2014.

25. Ratnawati D, Affandhy L: Performan Reproduksi Sapi Jantan dengan Pakan Berbasis Limbah Sawit. Seminar Nasional Teknologi Peternakan dan Veteriner. 2013; 4952.

26. Khairi F: Evaluasi Produksi dan Kualitas Semen Sapi Simmental terhadap Tingat Bobot Badan Berbeda. Jurnal Peternakan. 2016; 13(2): 54-58.

27. Zaini Z, Dasrul, Wahyuni S, et al. : Karakteristik semen dan komposisi kimia plasma seminalis sapi Aceh yang dipelihara di BIBD Saree Aceh Besar. Agrivet. 2016; 16 (2): 121-130.

28. Prastowo S, Dharmawan P, Nugroho T, et al. : Age effect on Bali cattle (Bos javanicus) fresh semen quality. Jurnal Ilmu Peternakan. 2018; 18(1): 1-8

29. Melita D, Dasrul, Adam M: The effect of bull age and ejaculation frequency on quality of Aceh bull spermatozoa. Jurnal Medika Veterinaria. 2014; 8(1): 1519.

30. Saputra DJ, Ihsan NM, Isnaini N: Korelasi antara lingkar skrotum dengan volume semen, konsentrasi dan motilitas spermatozoa pejantan sapi Bali. J. Trop. Anim. Prod. 2017; 18(2): 59-68.

31. Irwansyah $\mathrm{M}$ : Hubungan lingkar skrotum dengan kualitas dan kuantitas semen sapi Bali di (UPTD-IB) Desa Puncak Kecamatan Tumpobulu Kabupaten Maros. Skripsi. Makasar. Fakultas Kedokteran Hewan. Universitas Hasanuddin. 2015.

32. Nabilla A, Arifiantini RI, Purwantara B: Kualitas semen segar sapi Bali umur produktif dan non-produktif serta penentuan konsentrasi krioprotektan dalam pengencer tris kuning telur. Jurnal Veteriner. 2018; 19(2): 242-250.

33. Rachmawati L, Ismaya, Astuti P: Correlation between testosterone, libido, and sperm quality of Bligon, Kejobong and Ettawa Grade bucks. Buletin Peternakan. 2014; 38(1): 8-15. 